\title{
KARAKTERISASI MORFOLOGI DAN KUALITAS BERBAGAI AKSESI KATUK (Sauropus androgynus (L.) Merr.)
}

\author{
Morphological Characterization and Quality of Various Accessions of Star Gooseberry \\ (Sauropus androgynus (L.) Merr.)
}

\author{
T. Santana ${ }^{\mathrm{a}}$, A. Rahayu ${ }^{\mathrm{b}}$, Y. Mulyaningsih ${ }^{\mathrm{b}}$ \\ ${ }^{a}$ Mahasiswa S1 Jurusan Agroteknologi, Fakultas Pertanian, Universitas Djuanda Bogor \\ ${ }^{\mathrm{b}}$ Staf Pengajar Jurusan Agroteknologi, Fakultas Pertanian, Universitas Djuanda Bogor \\ Jl. Tol Ciawi 1, Kotak Pos 35 Bogor 16720 \\ *Email korespondensi: tatang.santana@ unida.ac.id
}

Diterima 15 Maret 2021/Disetujui 27 April 2021

\begin{abstract}
ABSTRAK
Katuk (Sauropus androgynus (L.) Merr) merupakan tanaman indigenous yang memiliki perbedaan karakter morfologi dan kualitas antar aksesi (daerah asal). Penelitian ini bertujuan untuk mengetahui perbedaan karakter morfologi dan kualitas berbagai aksesi tanaman katuk. Penelitian ini menggunakan rancangan acak lengkap (RAL) satu faktor, yaitu 10 aksesi katuk (Kadudampit1, Kadudampit2, Sukaraja, Pabuaran1, Pabuaran2, Leuwiliang, Kemang, Sentul, Pandeglang, Cianjur). Hasil penelitian ini menunjukkan bahwa pertambahan tinggi tanaman, panjang tunas, lebar anak daun, panjang anak daun dan luas anak daun terbaik adalah aksesi Pabuaran2, Kadudampit2 dan Kadudampit1. Aksesi katuk dengan pertambahan jumlah daun, jumlah anak daun, jumlah tunas dan panjang tunas tertinggi adalah Cianjur dan Kemang. Terdapat tiga kelompok tanaman katuk dengan tingkat kemiripan sebesar 76,27\%. Tingkat kemiripan tertinggi, sebesar 93,36\% terdapat pada aksesi Kadudampit1 dengan Sukaraja dan aksesi Kadudampit2 dengan Pabuaran2.
\end{abstract}

Kata kunci: indigenous, karakterisasi, tingkat kemiripan

\section{ABSTRACT}

Star gooseberry (Sauropus androgynus (L.) Merr) is an indigenous plant which has various accessions originating from many regions. These accessions have different morphological and quality characters. A completely randomized design with one factor consisting of 10 star gooseberry accessions, namely Kadudampit1, Kadudampit2, Sukaraja, Pabuaran1, Pabuaran2, Leuwiliang, Kemang, Sentul, Pandeglang, and Cianjur, was used. Results showed that the best increment in plant height, bud length, leaflet width, leaflet length, and leaflet area was found in Pabuaran2, Kadudampit2, and Kadudampit1 accessions. The highest increment in number of leaves, number of leaflets, number of buds, and bud length was found in Cianjur and Kemang accessions. There were three accessions which had morphological similarity level of $76.27 \%$. The highest morphological similarity level of 93.6\% was found between Kadudampit 1 and Sukaraja accessions and Kadudampit2 and Pabuaran2 accessions.

Keywords: characterization, indigenous, similarity level

\section{PENDAHULUAN}

Tanaman indigenous merupakan tanaman asli daerah yang telah banyak diusahakan dan dikonsumsi masyarakat, atau sayuran introduksi yang telah berkembang lama dan dikenal masyarakat di suatu daerah tertentu (Putrasamedja 2005). Katuk merupakan salah satu tanaman indigenous yang tumbuh baik di Indonesia, tergolong tanaman semak tahunan yang memiliki adaptasi tropika dan subtropika serta produktif sepanjang tahun (Rohmawati 2013). Kandungan nutrisi dalam $100 \mathrm{~g}$ katuk, terdiri atas 24,0 kkal energi, 79,4\% air, 7,6\% protein, $1,8 \%$ lemak, 6,9\% karbohidrat, 1,9\% serat, 2,0\% abu, $64 \mathrm{mg}$ P, $2610 \mathrm{mg} \mathrm{K}, 234 \mathrm{mg} \mathrm{Ca}, 3,1$ $\mathrm{mg}$ Fe dan $136 \mathrm{mg}$ vitamin $\mathrm{C}$ (Hoe dan Siong 1999).

Di Indonesia daun katuk secara turun temurun dimanfaatkan secara tradisional untuk mengobati demam, bisul, mencegah konstipasi, borok dan sebagai 
antioksidan (Handayani 2007), karena mengandung flavonoid (Kusumanegara 2017). Daun katuk dapat digunakan sebagai pewarna hijau alami tanpa menimbulkan residu (Hardjanti 2008). Selain itu, menurut Bunawan et al. (2015) di Indonesia dan Malaysia daun katuk diyakini dapat meningkatkan produktivitas ASI, di Thailand akar katuk digunakan untuk mengobati keracunan dan sebagai agen antiseptik, di Taiwan katuk digunakan sebagai agen pelangsing, sedangkan di India digunakan sebagai antidiabetes dan memperbaiki penglihatan.

Sayuran indigenous termasuk katuk di berbagai negara memiliki tingkat kepunahan yang tinggi, karena mulai tergeser oleh jenis sayuran lain yang lebih komersial (Handayani 2007). Upaya untuk meningkatkan manfaat dan mempertahankan plasma nutfah dapat dilakukan dengan koleksi (Putrasamedja 2005), lalu dikarakterisasi untuk mengetahui sifat-sifat dan karakter morfologinya (Hermanto 2008). Ciri morfologi bersifat fleksibel, dapat diamati secara kasat mata untuk melihat fenotipe suatu tanaman dan mudah dipengaruhi oleh lingkungan (Makmur 2016). Menurut Sutandi (2017) morfologi tanaman katuk asal Sukabumi, Cianjur dan Bogor memiliki kemiripan, diantaranya jumlah mahkota yang sama, yaitu berjumlah 6 mahkota, bertipe kelamin monoecious.

Penelitian ini bertujuan untuk mengetahui perbedaan karakter morfologi dan kimia berbagai aksesi tanaman katuk (Sauropus androgynus (L.) Merr.).

\section{MATERI DAN METODE}

\section{Waktu dan Tempat}

Penelitian ini dilaksanakan pada bulan April-September 2018 di Kebun Percobaan Program Studi Agroteknologi Universitas Djuanda Bogor. Penghitungan kandungan vitamin $\mathrm{C}$ dan klorofil dilaksanakan pada bulan September 2018 di Laboratorium Biologi Universitas Djuanda Bogor.

\section{Alat dan Bahan}

Alat yang digunakan pada penelitian ini diantaranya alat pengolahan tanah, gunting setek, embrat, timbangan, penyemprot pestisida dan alat-alat laboratorium. Bahan yang digunakan adalah polibeg, bibit tanaman katuk, media tanam (tanah, pupuk kompos dan arang sekam), pupuk sintetik (urea, SP-36, KCl), insektisida, pestisida, dan herbisida, bahan analisis kandungan klorofil dan vitamin $\mathrm{C}$ anak daun (aquades, aseton $85 \%$, iodium $0,01 \mathrm{~N}$, dan amilum $1 \%$ ).

\section{Metode Penelitian}

Penelitian ini menggunakan Rancangan Acak Lengkap (RAL) satu faktor, yaitu 10 aksesi katuk dengan tiga ulangan, sehingga terdapat 30 satuan percobaan. Setiap satuan percobaan terdiri atas 10 tanaman, sehingga seluruhnya terdapat 300 satuan amatan. Data dari setiap percobaan dianalisis dengan sidik ragam (Uji $\mathrm{F}$ ), dan jika perlakuan berpengaruh nyata dilakukan uji lanjut DMRT (Duncan's multiple range test) pada taraf $5 \%$.

\section{Pelaksanaan Penelitian}

Bahan tanaman katuk diperbanyak terlebih dahulu dengan setek batang, dengan panjang setek $\pm 25 \mathrm{~cm}$. Setek tanaman katuk ditanam dalam polibeg ukuran $20 \mathrm{~cm}$ x $12 \mathrm{~cm}$. Media setek yang digunakan adalah tanah, arang sekam dan pupuk kompos dengan perbandingan 1:1:1. Setek tanaman katuk dipindah tanam setelah berumur 45 hari ke polibeg berukuran $30 \times 40 \mathrm{~cm}$. Media tanam yang digunakan adalah tanah dan arang sekam dengan perbandingan 1:1. Jarak tanam antar polibeg 50 x $30 \mathrm{~cm}$ (Rohmawati 2013). Penanaman di lapangan dilakukan pada waktu pagi dan sore hari.

Penyiraman disesuaikan dengan kondisi cuaca, apabila tidak hujan maka dilakukan penyiraman secara manual, pada sore hari. Penyiangan gulma dilakukan setiap minggu secara manual. Pengendalian hama penyakit dilakukan dua 
minggu sekali menggunakan pestisida. Pupuk kandang dan SP-36 diberikan 100\% sebagai pupuk dasar pada awal penanaman, sedangkan pupuk urea dan $\mathrm{KCl}$ diberikan secara bertahap, $50 \%$ digunakan sebagai pupuk dasar, dan $25 \%$ sebagai pupuk susulan pada umur 3 dan 6 MST (Rohmawati 2013). Hal ini disebabkan pupuk urea bekerja cepat dan mudah hilang, sehingga tidak diberikan sekaligus.

Pemanenan dimulai pada umur 8 MST, panen selanjutnya sampai panen ketiga dilakukan secara kondisional sesuai dengan kesiapan panen yakni sampai panjang tunas baru $\pm 30 \mathrm{~cm}$ untuk setiap kultivarnya. Pemanenan dilakukan dengan cara memotong bagian pucuk daun atau cabang yang masih muda sepanjang $25 \mathrm{~cm}$. Pengujian di laboratorium dilaksanakan di akhir penelitian, setelah pengamatan di lapangan selesai.

\section{Peubah yang Diamati}

Pengamatan karakterisasi dilakukan dengan mengukur tanaman secara kuantitatif dan kualitatif. Pengamatan karakterisasi dilakukan dengan mengamati ciri-ciri morfologi yang terdapat pada masing-masing tanaman. Pengamatan data kualitatif morfologi tanaman mengacu pada penelitian Hermanto (2008) yang dimodifikasi. Data kuantitatif merupakan data terukur dari setiap spesies tanaman. Pengamatan data kuantitatif yang dilakukan meliputi pengamatan pertumbuhan tanaman dan data karakterisasi.

\section{Data Kualitatif}

Karakter kualitatif yang diamati secara umum, meliputi :

1. Karakter batang (bentuk batang dan warna batang).

2. Karakter daun (bentuk (bangun) daun, ujung daun, pangkal daun, tepi daun, daging daun, permukaan bagian/atas daun, warna daun dan belahan daun).
3. Karakter bunga dan buah (tipe kelamin, warna bunga jantan dan bunga betina, warna buah dan warna daging buah)

\section{Data Kuantitatif}

Karakter kuantitatif yang diamati secara umum, meliputi :

1. Tinggi tanaman yang diukur dari permukaan tanah hingga ujung titik tumbuh, diukur setiap satu minggu sekali mulai dari umur 3 MST sampai dengan 8 MST.

2. Diameter batang, diukur pada batang setinggi $10-20 \mathrm{~cm}$ dari permukaan tanah, setiap satu minggu sekali mulai dari umur 3 MST-8 MST.

3. Panjang, lebar daun dan luas daun diukur pada anak daun terluas pada daun ke 3 dari pucuk.

4. Panjang tunas dan jumlah tunas

5. Jumlah daun dan jumlah anak daun.

6. Diameter bunga jantan dan bunga betina.

7. Kandungan klorofil dan kandungan vitamin $\mathrm{C}$ diamati setelah pengamatan di lapangan.

\section{HASIL DAN PEMBAHASAN}

Selama percobaan berlangsung, kondisi hari tanpa hujan berkisar antara 8 18 hari dengan rata-rata curah hujan $197,33 \mathrm{~mm} /$ bulan. Kondisi suhu lapangan berkisar antara $20,5-31,7^{\circ} \mathrm{C}$ dengan lama penyinaran antara 60-70\%, dan kelembaban udara rata-rata $83 \%$ (BMKG 2018). Selama percobaan dijumpai hama berupa ulat, belalang dan siput pemakan daun. Pengendalian hama ulat dan belalang dilakukan secara kimiawi, sedangkan pengendalian hama siput dilakukan secara manual.

Hasil pengamatan karakterisasi kuantitatif dan kualitatif tanaman katuk menunjukkan semua peubah percobaan berpengaruh nyata dan memiliki karakter yang berbeda. Katuk aksesi Leuwiliang memiliki perbedaan yang cukup jauh dengan aksesi lainnya pada karakter warna daun. 


\section{Pertumbuhan Tanaman}

Pertambahan tinggi tanaman katuk aksesi Pabuaran 2 tidak berbeda nyata dengan aksesi Kadudampit 2 dan Kadudampit 1, tetapi lebih besar dibandingkan aksesi lain (Tabel 1).

Tabel 1. Pertambahan tinggi tanaman, jumlah daun, jumlah anak daun, jumlah tunas dan panjang tunas total pada umur 8 MST

\begin{tabular}{llllll}
\hline Aksesi & $\begin{array}{l}\text { Pertambahan } \\
\text { tinggi } \\
\text { tanaman }(\mathrm{cm})\end{array}$ & $\begin{array}{l}\text { Pertambahan } \\
\text { jumlah daun } \\
\text { tangkai) }\end{array}$ & $\begin{array}{l}\text { Pertambahan } \\
\text { jumlah anak } \\
\text { daun (helai) }\end{array}$ & $\begin{array}{l}\text { Jumlah } \\
\text { tunas }\end{array}$ & $\begin{array}{l}\text { Panjang tunas } \\
\text { total }(\mathrm{cm})\end{array}$ \\
\hline Kadudampit1 & $8,84^{\mathrm{b}}$ & $2,45^{\mathrm{abc}}$ & $9,66^{\mathrm{a}}$ & $0,53^{\mathrm{ab}}$ & $20,80^{\mathrm{bcd}}$ \\
Kadudampit2 & $13,89^{\mathrm{c}}$ & $2,8^{\mathrm{bc}}$ & $9,15^{\mathrm{a}}$ & $0,66^{\mathrm{abcd}}$ & $27,60^{\mathrm{d}}$ \\
Sukaraja & $3,40^{\mathrm{a}}$ & $1,90^{\mathrm{a}}$ & $7,70^{\mathrm{a}}$ & $0,60^{\mathrm{abc}}$ & $9,56^{\mathrm{a}}$ \\
Pabuaran1 & $4,33^{\mathrm{a}}$ & $3,07^{\mathrm{c}}$ & $17,97^{\mathrm{c}}$ & $0,37^{\mathrm{a}}$ & $22,00^{\mathrm{a}}$ \\
Pabuaran2 & $14,14^{\mathrm{c}}$ & $3,00^{\mathrm{bc}}$ & $10,53^{\mathrm{ab}}$ & $0,68^{\mathrm{abcd}}$ & $26,94^{\mathrm{cd}}$ \\
Leuwiliang & $5,11^{\mathrm{ab}}$ & $4,18^{\mathrm{d}}$ & $24,90^{\mathrm{d}}$ & $0,87^{\mathrm{bcd}}$ & $16,37^{\mathrm{abc}}$ \\
Kemang & $2,83^{\mathrm{a}}$ & $4,87^{\mathrm{de}}$ & $31,50^{\mathrm{e}}$ & $0,93^{\mathrm{cd}}$ & $13,00^{\mathrm{ab}}$ \\
Sentul & $6,40^{\mathrm{ab}}$ & $2,17^{\mathrm{ab}}$ & $14,07^{\mathrm{bc}}$ & $0,42^{\mathrm{a}}$ & $9,13^{\mathrm{a}}$ \\
Pandeglang & $3,32^{\mathrm{a}}$ & $2,98^{\mathrm{bc}}$ & $22,16^{\mathrm{d}}$ & $0,51^{\mathrm{ab}}$ & $7,98^{\mathrm{b}}$ \\
Cianjur & $3,72^{\mathrm{a}}$ & $5,23^{\mathrm{e}}$ & $31,08^{\mathrm{e}}$ & $1,03^{\mathrm{d}}$ & $25,34^{\mathrm{cd}}$ \\
\hline
\end{tabular}

Keterangan: Nilai rata-rata pada kolom yang sama diikuti huruf yang sama tidak berbeda nyata menurut uji DMRT pada taraf 5\%

Pertambahan jumlah daun aksesi Cianjur tidak berbeda nyata dengan aksesi Kemang, tetapi nyata lebih banyak dibandingkan dengan tanaman katuk aksesi lainnya. Pertambahan jumlah anak daun katuk aksesi Cianjur dan Kemang nyata lebih banyak dibandingkan dengan aksesi lainnya. Pertambahan jumlah tunas katuk aksesi Cianjur tidak berbeda nyata dengan aksesi Leuwiliang dan Kemang, tetapi nyata lebih besar dibandingkan dengan tanaman katuk aksesi lainnya. Pertambahan panjang tunas katuk aksesi Kadudampit2 tidak berbeda nyata dengan aksesi Kadudampit1, Pabuaran2 dan Cianjur, tetapi nyata lebih besar dibandingkan dengan tanaman katuk aksesi lainnya (Tabel 1).

Tabel 2. Pertambahan diameter batang, panjang daun, lebar daun dan luas daun pada umur 8 MST

\begin{tabular}{lcccc}
\hline & $\begin{array}{c}\text { Pertambahan } \\
\text { diameter batang } \\
(\mathrm{cm})\end{array}$ & $\begin{array}{c}\text { Panjang Daun } \\
(\mathrm{cm})\end{array}$ & $\begin{array}{c}\text { Lebar Daun } \\
(\mathrm{cm})\end{array}$ & $\begin{array}{c}\text { Luas Daun } \\
\left(\mathrm{cm}^{2}\right)\end{array}$ \\
\hline Kadudampit1 & $0,04^{\mathrm{abc}}$ & $6,73^{\mathrm{ef}}$ & $3,33^{\mathrm{c}}$ & $17,52^{\mathrm{cd}}$ \\
Kadudampit2 & $0,07^{\mathrm{d}}$ & $5,97^{\mathrm{de}}$ & $3,00^{\mathrm{c}}$ & $16,11^{\mathrm{c}}$ \\
Sukaraja & $0,04^{\mathrm{ab}}$ & $6,20^{\mathrm{def}}$ & $3,27^{\mathrm{c}}$ & $17,15^{\mathrm{cd}}$ \\
Pabuaran1 & $0,03^{\mathrm{a}}$ & $2,60^{\mathrm{a}}$ & $1,63^{\mathrm{a}}$ & $3,46^{\mathrm{a}}$ \\
Pabuaran2 & $0,07^{\mathrm{cd}}$ & $7,20^{\mathrm{f}}$ & $3,23^{\mathrm{c}}$ & $20,28^{\mathrm{d}}$ \\
Leuwiliang & $0,06^{\mathrm{bcd}}$ & $4,40^{\mathrm{bc}}$ & $2,27^{\mathrm{b}}$ & $8,74^{\mathrm{b}}$ \\
Kemang & $0,06^{\mathrm{cd}}$ & $5,20^{\mathrm{cd}}$ & $2,17^{\mathrm{ab}}$ & $9,71^{\mathrm{b}}$ \\
Sentul & $0,04^{\mathrm{ab}}$ & $4,73^{\mathrm{bc}}$ & $2,47^{\mathrm{b}}$ & $10,39^{\mathrm{b}}$ \\
Pandeglang & $0,03^{\mathrm{a}}$ & $4,13^{\mathrm{b}}$ & $2,17^{\mathrm{ab}}$ & $8,08^{\mathrm{b}}$ \\
Cianjur & $0,06^{\mathrm{bcd}}$ & $2,17^{\mathrm{b}}$ & $2,17^{\mathrm{ab}}$ & $7,96^{\mathrm{b}}$ \\
\hline
\end{tabular}

Keterangan: Nilai rata-rata pada kolom yang sama diikuti huruf yang sama tidak berbeda nyata menurut uji DMRT pada taraf 5\% 
Aksesi katuk Kadudampit 2 memiliki diameter batang lebih besar dibandingkan dengan aksesi Kadudampit1, Sukaraja, Pabuaran1, Sentul dan Pandeglang, namun tidak berbeda nyata dengan aksesi Pabuaran2, Leuwiliang, Kemang, dan Cianjur. Panjang. Luas anak daun katuk aksesi Pabuaran2 tidak berbeda nyata dengan aksesi Kadudampit1 dan Sukaraja, tetapi nyata lebih besar dibandingkan dengan aksesi lainnya. Lebar anak daun katuk aksesi Sukaraja tidak berbeda nyata dengan aksesi Pabuaran2, aksesi Kadudampit1 dan aksesi Kadudampit2, tetapi nyata lebih lebar jika dibandingkan dengan aksesi lainnya (Tabel 2).

\section{Kandungan Vitamin C dan Klorofil}

Daun katuk aksesi Cianjur memiliki kandungan vitamin $\mathrm{C}$ lebih tinggi dibandingkan dengan aksesi lainnya, namun tidak berbeda nyata dengan aksesi Kadudampit2. Kandungan klorofil a katuk aksesi Sentul lebih tinggi dibandingkan aksesi lainnya, namun tidak berbeda nyata dengan aksesi Sukaraja, Pabuaran2, dan Kadudampit2. Kandungan klorofil b katuk aksesi Kemang, Kadudampit2, Sukaraja, Pabuaran2 dan Cianjur lebih tinggi dibandingkan aksesi lainnya, sedangkan kandungan klorofil total katuk aksesi Sukaraja, Sentul, Pandeglang, Cianjur dan Pabuaran2 lebih tinggi dibandingkan aksesi lainnya (Tabel 3).

Tabel 3 Kandungan vitamin C dan klorofil daun katuk

\begin{tabular}{|c|c|c|c|c|}
\hline \multirow{3}{*}{ Aksesi } & \multirow{2}{*}{ Vitamin C } & \multicolumn{3}{|c|}{ Kandungan Klorofil } \\
\hline & & Klorofil a & Klorofil b & Klorofil Total \\
\hline & ----mg/100g---- & \multicolumn{3}{|c|}{----------------mg/g-------------- } \\
\hline Kadudampit1 & $83,31^{\mathrm{a}}$ & $2,69^{b}$ & $1,70^{\mathrm{b}}$ & $4,39^{\mathrm{a}}$ \\
\hline Kadudampit2 & $328,53^{\mathrm{cd}}$ & $4,63^{\mathrm{ef}}$ & $1,24^{\mathrm{a}}$ & $5,87^{\mathrm{cd}}$ \\
\hline Sukaraja & $88,00^{\mathrm{a}}$ & $4,74^{\mathrm{ef}}$ & $1,61^{\mathrm{b}}$ & $6,35^{\mathrm{e}}$ \\
\hline Pabuaran1 & $75,09^{\mathrm{a}}$ & $4,49^{\mathrm{e}}$ & $1,18^{\mathrm{a}}$ & $5,66^{\mathrm{bc}}$ \\
\hline Pabuaran2 & $315,63^{\mathrm{bc}}$ & $4,71^{\mathrm{ef}}$ & $1,34^{\mathrm{a}}$ & $6,05^{\mathrm{de}}$ \\
\hline Leuwiliang & $306,24^{\mathrm{bc}}$ & $4,12^{\mathrm{d}}$ & $1,30^{\mathrm{a}}$ & $5,42^{\mathrm{b}}$ \\
\hline Kemang & $292,16^{\mathrm{bc}}$ & $1,94^{\mathrm{a}}$ & $3,45^{\mathrm{d}}$ & $5,39^{\mathrm{b}}$ \\
\hline Sentul & $252,27^{b}$ & $4,90^{\mathrm{f}}$ & $1,40^{\mathrm{a}}$ & $6,30^{\mathrm{e}}$ \\
\hline Pandeglang & $283.95^{\mathrm{bc}}$ & $3.83^{c}$ & $2.45^{\mathrm{c}}$ & $6.28^{\mathrm{e}}$ \\
\hline Cianjur & $382,51^{\mathrm{d}}$ & $4,74^{\mathrm{ef}}$ & $1,36^{\mathrm{a}}$ & $6,10^{\text {de }}$ \\
\hline
\end{tabular}

Keterangan: Nilai rata-rata pada kolom yang sama diikuti huruf yang sama tidak berbeda nyata menurut uji DMRT pada taraf 5\%

\section{Pembahasan Pengamatan Kuantitatif}

Aksesi yang memiliki pertambahan tinggi tanaman yang besar mengindikasikan bahwa aksesi tersebut memiliki panjang tunas, panjang, lebar dan luas daun yang baik. Luas permukaan daun diduga dapat meningkatkan laju fotosintesis. Menurut Buntoro et al. (2014), daun merupakan organ utama untuk menyerap cahaya matahari, pada daun yang lebar tanaman akan mampu menyerap cahaya matahari yang lebih banyak. Energi cahaya kemudian diubah menjadi energi kimia (ATP dan NADPH), lalu digunakan untuk reduksi $\mathrm{CO}_{2}$ menjadi senyawa karbohidrat yang digunakan untuk menyusun struktur dan fungsi dalam tanaman (Anni et al. 2013). Selain itu, aksesi tersebut diduga memiliki kemampuan menyerap hara P dengan baik. Menurut Rohmawati (2013), tanaman katuk yang ditambahkan pupuk $\mathrm{P}$ pada tanah hanya memberikan pengaruh pada tinggi tanaman, tapi tidak pada hasil. Perbedaan luas dan ketebalan daun diduga berpengaruh terhadap penyerapan energi surya dan hilangnya air melalui proses transpirasi, serta intensitas difusi cahaya oleh sel-sel palisade (Sari et al. 2016). Menurut Sopandie (2014), peningkatan 
$\mathrm{CO}_{2}$ menyebabkan perubahan anatomi daun, sehingga daun menjadi lebih tebal.

Aksesi yang memiliki jumlah tunas lebih banyak mengindikasikan bahwa tanaman tersebut memiliki jumlah daun dan jumlah anak daun lebih banyak. Hal ini diduga karena penyerapan $\mathrm{N}$ yang efektif dan aliran fotosintat yang lebih banyak diarahkan pada tunas. Hasil penelitian Hakim (2009) pada tanaman rosela, menunjukkan semakin besar dosis pemupukan $\mathrm{N}$ maka jumlah cabang produktif yang dihasilkan juga semakin banyak. Menurut Gardner et al. (1991) unsur $\mathrm{N}$ merupakan bahan penting dalam penyusunan asam amino dan esensial untuk pembelahan sel dan pembesaran sel.

Setiap aksesi memiliki kemampuan yang berbeda dalam penyerapan hara, sehingga terjadi perbedaan keragaan antar aksesi. Menurut Harjadi (1991) ketersediaan unsur hara bagi tanaman merupakan salah satu faktor penting untuk menunjang pertumbuhan dan perkembangan tanaman, yaitu sebagai sumber energi dan penyusun struktural tanaman.

Perbedaan karakter antar aksesi dimungkinkan juga karena kondisi asal aksesi yang berbeda. Menurut Suhartini (2010) keragaman antar maupun intraspesies disebabkan adanya perbedaan secara genetik, yaitu adanya perbedaan secara morfologi genom, dan kekerabatan yang jauh, selain itu faktor lingkungan juga berpengaruh, karena tumbuh di luar habitat aslinya.

\section{Karakterisasi Morfologi}

Hasil karakterisasi kualitatif 10 aksesi tanaman katuk menunjukkan keragaman karakter batang dan daun. Warna batang aksesi dibedakan atas hijau muda, hijau dan hijau tua. Bentuk (bangun) daun terdapat dua keragaman, yaitu bundar telur dan lanset. Karakter morfologi yang sama adalah bentuk batang, tepi daun, belahan daun, tipe kelamin, warna daging buah, jumlah kelopak dan warna kelopak (Tabel 4).
Daun katuk merupakan daun majemuk yang terdiri atas tangkai daun dan anak daun. Anak daun memiliki permukaan yang kesat dan helai daun tipis, selain itu terdapat bercak putih yang terpusat di tengah daun, mengikuti tulang daun dan menyebar pada permukaan daun. Daun katuk berbentuk bundar telur dan lanset, anak daun muda berwarna hijau muda dan hijau kekuningan sedangkan anak daun tua berwarna hijau dan hijau tua, pangkal daun tumpul, membundar dan runcing, ujung daun tumpul, runcing dan meruncing. Anak daun tersebut memiliki panjang 2,60-6,73 cm, lebar 1,63-3,33 cm dan luas 3,46-17,52 cm, lebih kecil dibandingkan dengan hasil penelitian Petrus (2013), daun katuk memiliki panjang 3-10 cm dan lebar 1,5-3,5 cm.

Bunga katuk bertipe kelamin monoecious, bunga betina terletak pada bagian ujung daun, sedangkan bunga jantan pada pangkal daun. Menurut Bahari (2017) tanaman katuk aksesi Cianjur memiliki bunga jantan lebih sedikit dibandingkan dengan bunga betina dan bunga jantannya mudah gugur, sehingga sering menghasilkan buah, sedangkan katuk aksesi Sukabumi 1 memiliki bunga jantan lebih banyak dibandingkan dengan bunga betina, katuk aksesi ini jarang menghasilkan buah. Bunga betina berwarna ungu-merah, memiliki 6 kelopak dan berdiameter $0,55-0,94 \mathrm{~cm}$, sedangkan bunga jantan berbentuk pipih berwarna krem-kuning muda dan berdiameter 0,6$1,12 \mathrm{~cm}$. Buah katuk berbentuk bulat, tekstur kulit buah bergelombang berwarna putih dan merah, daging buah berwarna putih dan biji berwarna hitam.

Karakter morfologi tanaman yang diamati, meliputi data kualitatif dan kuantitatif diuji untuk menjelaskan kekerabatan antar aksesi. Hasil pengujian karakter kualitatif dan kuantitatif disajikan dalam bentuk dendogram yang menunjukan tingkat kedekatan kekerabatan antar aksesi yang diuji (Gambar 1). 
Tabel 9 Karakter morfologi tanaman katuk

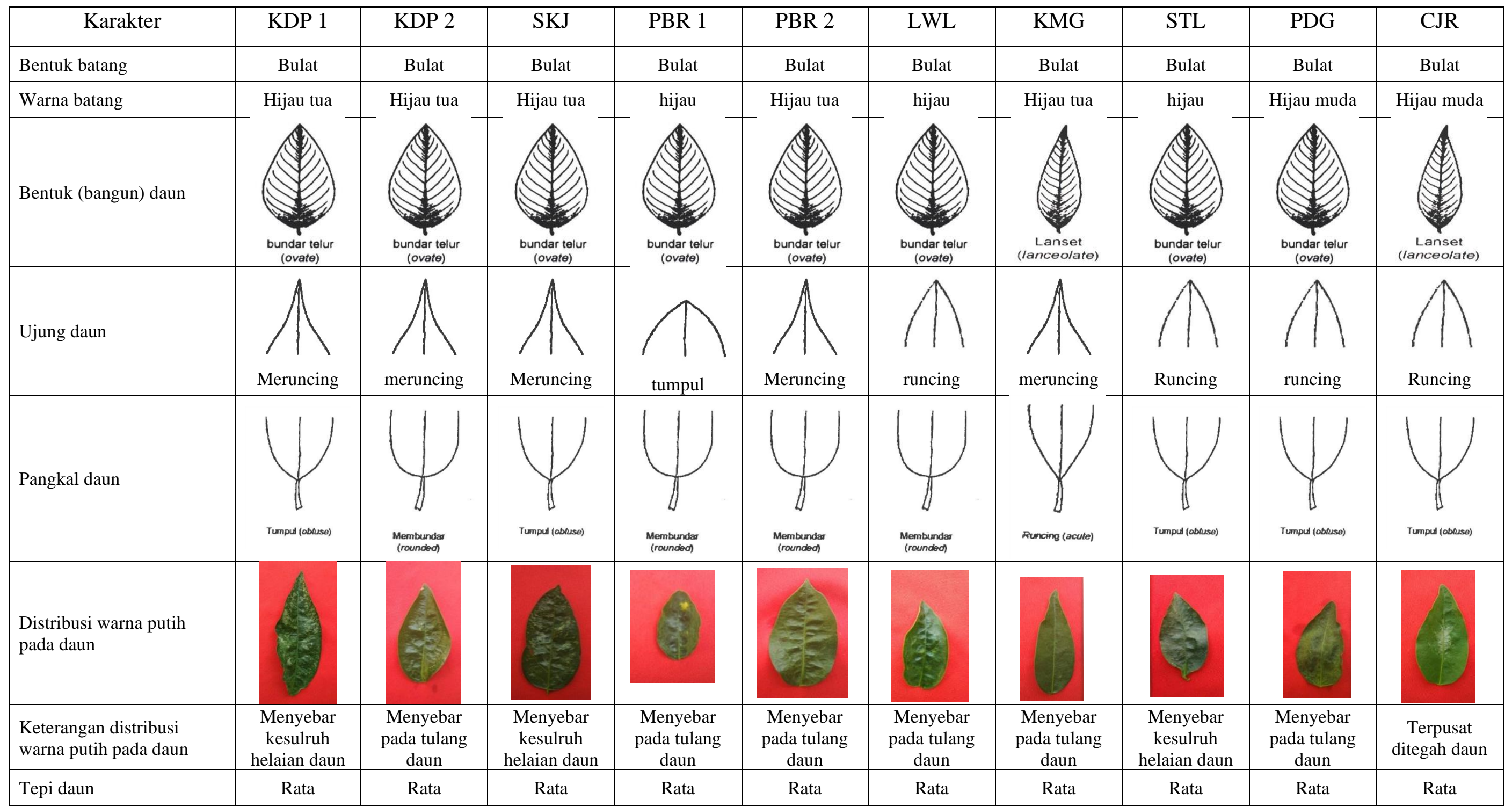


Lanjutan Tabel 9.

\begin{tabular}{|c|c|c|c|c|c|c|c|c|c|c|}
\hline Daging daun & Tipis & Tipis & Tipis & Tipis & Tipis & Seperti kulit & Tipis & Tipis & Tipis & Tipis \\
\hline Permukaan atas daun & Kesat & Kesat & Kesat & Kesat & Kesat & Kesat & Kesat & Kesat & Kesat & Kesat \\
\hline Warna daun muda & Hijau muda & Hijau muda & Hijau muda & $\begin{array}{c}\text { Hijau } \\
\text { kekuningan }\end{array}$ & Hijau muda & $\begin{array}{c}\text { Hijau } \\
\text { kekuningan }\end{array}$ & Hijau & Hijau muda & $\begin{array}{c}\text { Hijau } \\
\text { kekuningan }\end{array}$ & $\begin{array}{c}\text { Hijau } \\
\text { kekuningan }\end{array}$ \\
\hline Warna daun tua & Hijau tua & Hijau tua & Hijau tua & Hijau & Hijau tua & Hijau & Hijau tua & Hijau tua & Hijau tua & Hijau \\
\hline Belahan daun & Simetris & Simetris & Simetris & Simetris & Simetris & Simetris & Simetris & Simetris & Simetris & Simetris \\
\hline Tipe kelamin & Monoceous & Monoceous & Monoceous & Monoceous & Monoceous & Monoceous & Monoceous & Monoceous & Monoceous & Monoceous \\
\hline Warna bunga jantan & Krem & Krem & Krem & Kuning muda & Krem & Kuning muda & Kuning muda & Krem & Krem & Kuning muda \\
\hline Warna bunga betina & Ungu & Ungu & Ungu & Merah & Ungu & Merah & Ungu & Merah & Ungu & Merah \\
\hline Panjang daun (cm) & 6,73 & 5,97 & 6,20 & 2,60 & 7,20 & 4,40 & 5,20 & 4,73 & 4,13 & 2,17 \\
\hline Lebar daun $(\mathrm{cm})$ & 3,33 & 3,00 & 3,27 & 1,63 & 3,23 & 2,27 & 2,17 & 2,47 & 2,17 & 2,17 \\
\hline Warna buah & Merah & Merah & Merah & Putih & Putih & Putih & Merah & Putih & Putih & Putih \\
\hline Warna daging buuah & Putih & Putih & Putih & Putih & Putih & Putih & Putih & Putih & Putih & Putih \\
\hline Jumlah mahkota & 6 & 6 & 6 & 6 & 6 & 6 & 6 & 6 & 6 & 6 \\
\hline Warna mahkota & Merah & Merah & Merah & Merah & Merah & Merah & Merah & Merah & Merah & Merah \\
\hline $\begin{array}{l}\text { Diameter bunga jantan } \\
(\mathrm{cm})\end{array}$ & 1,09 & 0,88 & 1,12 & 0,71 & 1 & 1,11 & 0,6 & 0,72 & 0,83 & 0,87 \\
\hline $\begin{array}{l}\text { Diameter bunga betina } \\
(\mathrm{cm})\end{array}$ & 0,91 & 0,64 & 0,69 & 0,55 & 0,83 & 0,94 & 0,61 & 0,6 & 0,74 & 0,77 \\
\hline
\end{tabular}

Keterangan : KDP $1=$ Kadudampit 1, KDP $2=$ Kadudampit 2, SKJ = Sukaraja, PBR $1=$ Pabuaran 1, PBR $2=$ Pabuaran 2, LWL = Leuwiliang, $\mathrm{KMG}=\mathrm{Kemang}, \mathrm{STL}=$ Sentul, $\mathrm{PDG}=$ Pandeglang, $\mathrm{CJR}=$ Cianjur 
Berdasarkan karakter kualitatif dan kuantitatif tanaman katuk yang diuji, terdapat tiga kelompok tanaman katuk dengan tingkat kemiripan sebesar 76,27\%. Kelompok pertama terdiri atas aksesi Kadudampit1, Sukaraja, Kadudampit2 dan Pabuaran2. Kelompok kedua terdiri atas aksesi Pabuaran1, Sentul dan Pandeglang. Kelompok ketiga adalah aksesi Leuwiliang, Kemang dan Cianjur. Aksesi dengan tingkat kemiripan terbesar adalah aksesi Kadudampit1 dengan Sukaraja dan aksesi Kadudampit2 dengan Pabuaran2, yang tingkat kemiripannya sebesar 93,36\%. Aksesi Leuwiliang memiliki perbedaan yang cukup jauh dengan aksesi lainnya, hal ini disebabkan karakter kualitatif dan kuantitatif katuk aksesi Leuwiliang cukup berbeda dengan aksesi yang lain terutama pada ketebalan daun dan warna daun.

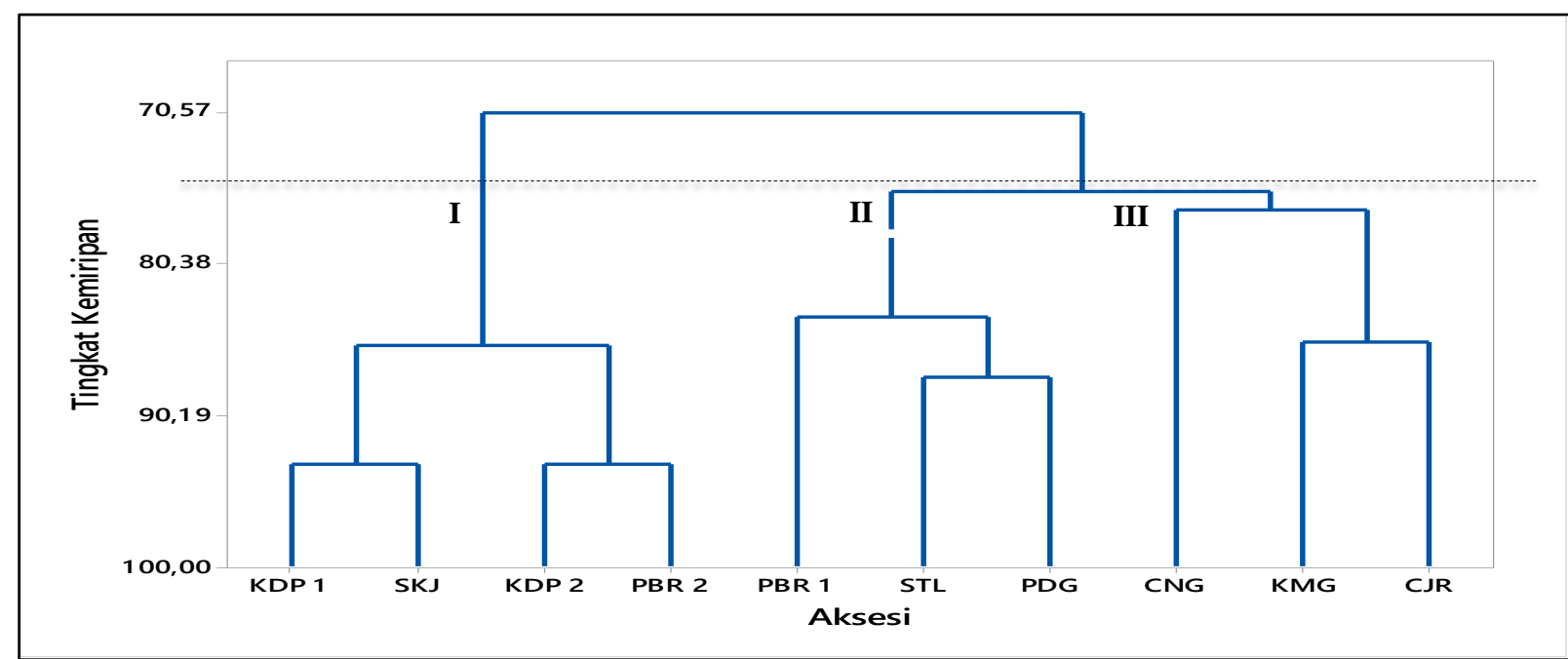

Keterangan : KDP 1 = Kadudampit 1, KDP 2 = Kadudampit 2, SKJ = Sukaraja, PBR $1=$ Pabuaran 1, PBR $2=$ Pabuaran 2, LWL = Leuwiliang, KMG = Kemang, STL = Sentul, PDG = Pandeglang, CJR = Cianjur

Gambar 1 Dendogram hasil deskripsi karakter kuantitatif dan kualitatif 10 aksesi tanaman katuk

\section{Karakter Kualitas}

Pada penelitian ini kualitas yang diukur adalah analisis vitamin $\mathrm{C}$ dan analisis klorofil. Kandungan vitamin C terbaik dimiliki oleh aksesi Cianjur. Menurut Maharani et al. (2015) vitamin C merupakan suatu asam organik, dan mudah rusak oleh oksidasi yang dipercepat pada suhu tinggi. Peningkatan kandungan vitamin $\mathrm{C}$ diduga akibat tanaman mengalami stres, karena pada saat percobaan terjadi iklim yang ekstrim dan kekurangan air. Menurut Fatchurrozak et al. (2013) ketika tanaman mengalami stres, maka produksi metabolit sekunder termasuk produksi vitamin $\mathrm{C}$ mengalami peningkatan.
Katuk aksesi Cianjur juga merupakan salah satu aksesi yang memiliki kandungan klorofil total terbaik setelah aksesi Sukaraja. Menurut Cahyati et al. (2014) kandungan vitamin C pada daun tua lebih tinggi dibandingkan dengan daun muda. Vitamin C merupakan salah satu bahan dasar pembangun struktur tubuh yang dihasilkan oleh fotosintat, sehingga dipengaruhi oleh kandungan klorofil. Menurut Prasetyo dan Laily (2015) klorofil penting bagi tumbuhan untuk melaksanakan fotosintesis dan menghasilkan energi. 


\section{KESIMPULAN}

Aksesi dengan pertambahan tinggi tanaman, lebar anak daun, panjang anak daun dan luas anak daun yang tinggi adalah Pabuaran2, Kadudampit2 dan Kadudampit1. Pertambahan jumlah daun, jumlah anak daun, jumlah tunas dan panjang tunas tertinggi adalah aksesi

\section{DAFTAR PUSTAKA}

Anni IA, Aptiningsih E, Haryanti S. 2013. Pengaruh naungan terhadap pertumbuhan dan produksi tanaman bawang daun (Allium fistulosum L.) di Bandungan, Jawa Tengah. Jurnal Biologi. 3(2):31-40.

Bahari F. 2017. Pengaruh urine sapi dan urea terhadap pertumbuhan, produksi, dan kualitas katuk (Sauropus androgynus (1.) Merr.). [Skripsi]. Bogor: Fakultas Pertanian. Universitas Djuanda Bogor.

BMKG. 2018. Buletin Informasi Iklim Jawa Barat. Bogor: Stasiun Klimatologi Bogor.

Bunawan H, Bunawan SN, Baharum SN, Noor NM. 2015. Sauropus androgynus (L.) Merr. induced bronchiolitis obliterans: From botanical studies to toxicology. Evidence-Based Complementary and Alternative Medicine. 1(1): 1-7.

Buntoro BH, Rogomulyo R, Trisnowati S. 2014. Pengaruh takaran pupuk kandang dan intensitas cahaya terhadap pertumbuhan dan hasil temu putih (Curcuma zedoaria L.). Vegetalika. 3(4):29-39.

Cahyati RD, Natsir H, Wahab AW. 2014. Analisis kadar asam askorbat dalam ekstrak daun kelor (Moringa oleifera Lam) dari daerah pesisir dan pegunungan serta potensinya sebagai antioksidan. Makassar: Universitas Hasanudin.
Cianjur dan Kemang. Berdasarkan karakterisasi kualitatif dan kuantitatif tanaman katuk yang diuji, terdapat tiga kelompok tanaman katuk dengan tingkat kemiripan sebesar 76,27 \%. Tingkat kemiripan tertinggi, sebesar 93,36 \% terdapat pada aksesi Kadudampit1 dengan Sukaraja dan aksesi Kadudampit2 dengan Pabuaran2.

Fatchurrozak, Suranto, dan Sugiyarto. 2011. Pengaruh ketinggian tempat terhadap kandungan vitamin $\mathrm{C}$ dan zat antioksidan pada buah Carica pubescens di dataran tinggi dieng, Jurnal Pasca UNS. 1(1):24-31.

Gardner FP, Pearce RB, dan Mitchell RL. 1991. Fisiologi Tanaman Budidaya (Pnjmh: Susilo, H.). Jakarta:UI Press.

Hakim AM. 2009. Asupan nitrogen dan pupuk organik cair terhadap hasil dan kadar vitamin c kelopak bunga rosela (Hibiscus sabdariffa L.). [Skripsi]. Surakarta: Fakultas Pertanian. Universitas Sebelas Maret.

Handayani D. 2007. Identifikasi karakter hortikultura beberapa sayuran indigenous. [Skripsi]. Bogor: Fakultas Pertanian. Institut Pertanian Bogor.

Hardjanti. 2008. Potensi daun katuk sebagai sumber zat pewarna alami dan stabilitasnya selama pengeringan bubuk dengan menggunakan binder maltodekstrin. Jurnal Penelitian Saintek. 13(1):118.

Harjadi SS. 1991. Pengantar Agronomi. Jakarta: Gramedia.

Hermanto D. 2008. Koleksi dan karakterisasi plasma nutfah sayuran indigenous. [Skripsi]. Bogor: Fakultas Pertanian. Institut Pertanian Bogor.

Hoe VB, Siong KH. 1999. The nutritional value of indigenous fruits and vegetables in sarawak. Asia Pacific 
Journal of Clinical Nutrition. 8(1):24-31.

Kusumanegara KS, Setiawan AS, Rachmawati E. 2017. The difference of inhibitory zone between katuk (Sauropus androgynus L. merr.) leaf infusion and roselle (Hibiscus sabdariffa L.) petals towards oral Candida albicans. Padjadjaran Journal of Dentistry. 29(2):118-122.

Maharani ETW, Yusrin, Mukaromah AH. 2015. Analisis vitamin c dan kalium pada daun binahong (Anredera cordifolia (TEN) Steenis). The 2nd University Research Colloquium. 441-444.

Makmur K. 2016. Analisis keragaman genetik kemangi (Ocimum $\times$ Africanum Lour.) berdasarkan marka morfologi dan inter-simple sequence repeats. [Tesis]. Bogor: Sekolah Pascasarjana. Institut Pertanian Bogor.

Petrus AJA. 2013. Sauropus androgynus (L.) Merrill-A potentially nutritive functional leafy-vegetable. Asian
Journal of Chemistry. 25(17):94259433.

Putrasamedja S. 2005. Eksplorasi dan koleksi sayuran indigenous di kabupaten karawang, purwakarta, dan subang. Buletin Plasma Nutfah. 11(1):16-20.

Rohmawati I. 2013. Penentuan dosis pemupukan $\mathrm{N}, \mathrm{P}$ dan $\mathrm{K}$ pada budidaya katuk (Sauropus androgynus (L.) Merr.). [Tesis]. Bogor: Sekolah Pascasarjana. Institut Pertanian Bogor.

Sopandie D. 2014. Fisiologi Adaptasi Tanaman Terhadap Cekaman Abiotik Pada Agroekosistem Tropika. Bogor: IPB Press.

Suhartini T. 2010. Keragaman karakter morfologis plasma nutfah spesies padi liar (Oryza spp.). Buletin Plasma Nutfah. 16(1):17-28.

Sutandi IA. 2017. Pengaruh naungan terhadap pertumbuhan, produktivitas dan karakteristik morfologi tanaman sayuran daun indigenous. [Skripsi]. Bogor: Fakultas Pertanian. Universitas Djuanda Bogor. 